\title{
小笠原諸島父島東岸の無人岩平行岩脈群
}

\author{
白木敬 一* 柴田論 男 ** \\ 黒 田 直 ${ }^{* * *}$ 浦 野隼 臣 $^{* * * *}$
}

\section{Boninite Parallel Dike Swarm on the East Coast of Chichi-jima, Bonin Islands}

\author{
Keiichi SHIRAKI*, Akio SHIBATA**, \\ Naoshi KURODA ${ }^{* * *}$ and Hayaomi URANO ${ }^{* * * *}$
}

\section{I. はじめに}

小笠原諸島父島で19世紀末, 菊池 (1888) が発 見し Petersen (1891) が命名した無人岩は長らく 忘れられていたが，Kuroda and Shiraki (1975), 白木・黒田 (1977) による再発見の後, 西太平洋 の背弧海盈を伴う島弧や世界各地のオフィオライ トから次々に見出され（白木，1989），島弧の初期 火成活動にかなり普遍的なものであることが明ら かになった (白木・藤岡, 1992)。無人岩は $\mathrm{MgO}$ に富むにもかかわらず $\mathrm{SiO}_{2}$ が高いという特異な 組成から，水を含みかつ高温のマントル浅所で生 ビたと推定され，特定の地質条件を表わす岩石と して注目されている（Crawford，1989）。

特に層状岩脈群（sheeted dike complex）がよ く発達し, 中央海嶺でっくられたオフィオライト の典型とされたキプロス島トルドス・オフィオラ イトでは，無人岩が発見された (Robinson et al., 1983) ことにより, トルドス・オフィオライ 卜は沈み込み帯の上の挔大中心で生じたと考えら れるようになった（Pearce et al., 1984 ; 白木ほ か, 1987)。一方, 父島の枕状溶岩層最下部には平 行岩脈群が存在し, 白木 (1988) はこれを100\%岩 脈からなる層状岩脈群に移行するものと考えた。 今回, 我々は東京地学協会助成金を得て, 父島東 岸の平行岩脈群を上記の観点から調査したので報 告する。

\section{II. 父島の地質概要}

父島は主に始新世の火山岩からなり, 無人岩と それから分化した安山岩・デイサイト・流紋岩に よって構成される。火山岩以外では, わずかに南 西端南島・南崎で厚さ $80 \mathrm{~m}$ 以上の 後期漸新世の 礁石灰岩が火山岩の上に不整合に載る。火山岩層 は二見湾に向かって緩く傾く盈状構造を示し, 父 島東海岸に最下部があらわれる。

\footnotetext{
* 山口大学理学部地球科学教室

** (株) ダイヤコンサルタント

*** 静岡大学理学部地球科学教室

**** 愛知教育大学地学教室

* Department of Earth Sciences, Faculty of Science, Yamaguchi University

** DIA Consultants, Ltd.

*** Institute of Geosciences, School of Science, Shizuoka University

**** Department of Earth Science, Aichi Educational University
} 


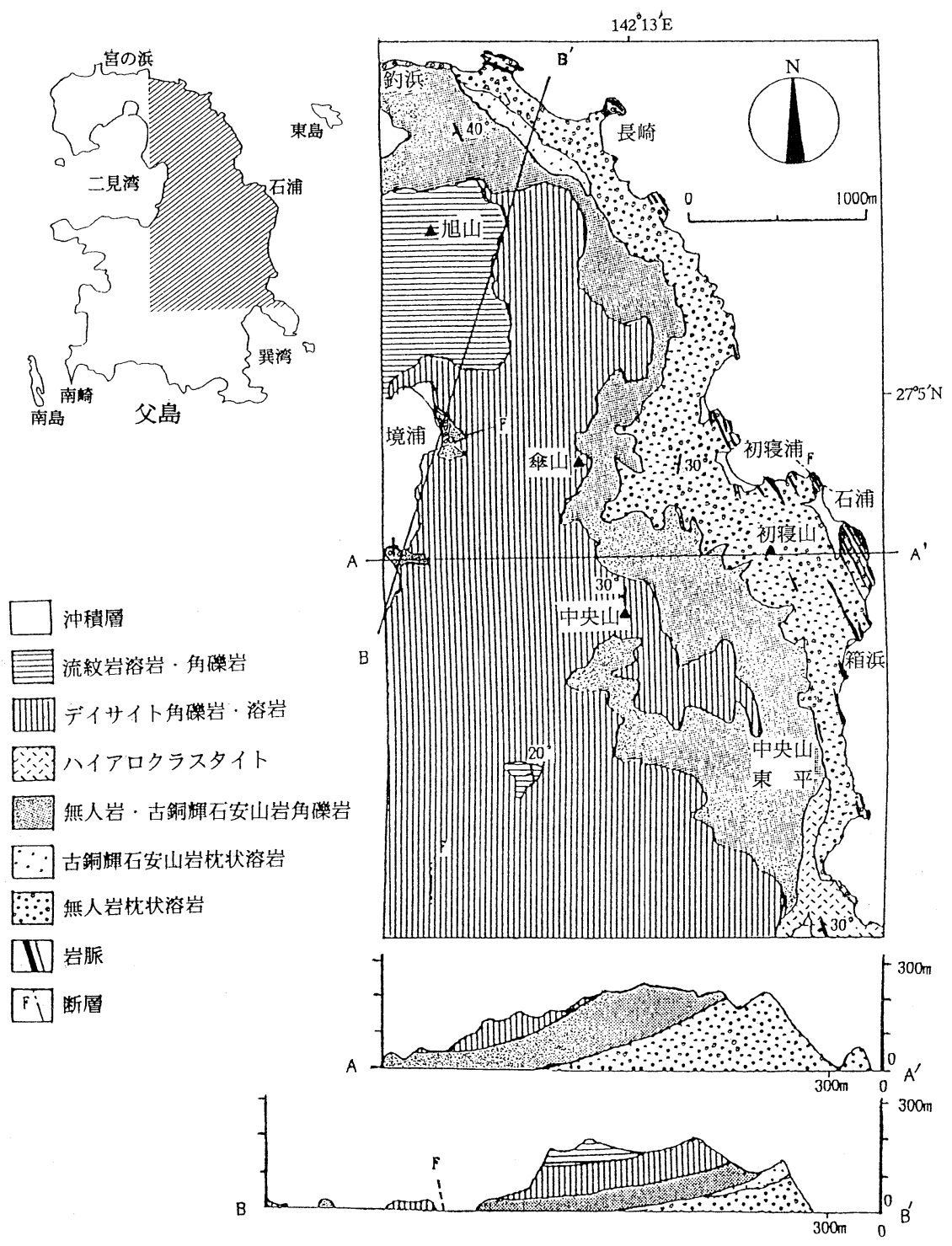

図 1 父島東部の地質図 $\cdot$ 断面図

父島東部の地質図々断面図を図 1 に示す。父島 東部の火山岩は下位加ら無人岩枕状溶岩, 古銅輝 石安山岩枕状溶岩, 無人岩・古銅輝石安山岩角碟 岩およびハイアロクラスタイト，デイサイト角砂 岩・溶岩, 流紋岩溶岩・角礫岩の各層に分けられ る。これら各層は明膫に分かれるのではなく, 互 いに漸移し，一般に下部は無人岩質の枕状溶岩, 上部はデイサイト質の角磁岩が多い。最下部の無 人岩枕状溶岩を主体とする層は, 初寝山周辺で厚
さ300 $\mathrm{m}$ 以上に達する。Umino（1985）は, デイ サイト角砼岩・溶岩層以下を円縁湾累層, 流紋岩 溶岩・角砂岩層を旭山累層と名づけた。円縁湾累 層は全体で少なくとも $600 \mathrm{~m}$ 以上の厚さをもち， 旭山累層の最も厚い部分は $200 \mathrm{~m}$ に達する。

岩脈は各所に見られるが，特に父島東岸から北 西に向かって父島北岸および兄島南西岸に多い。

円縁湾累層上部を貫く岩脈は, 比較的大規模で, 幅 $10 \mathrm{~m}$ 以上, $100 \mathrm{~m}$ 以上にわたって延びるもの 


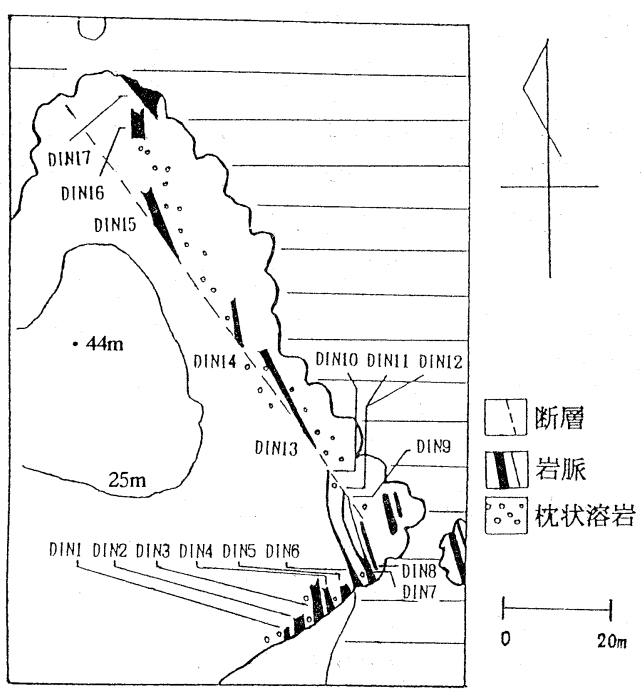

図 2 石浦北海岸の平行岩脈群

もある。岩質は例外なくデイサイトである。また いくつかの場所で上方に向かって枕状構造をもつ 溶岩流に移り変わるのが観察される。

父島北岸および兄島南西岸の岩脈もデイサイト が多いが，稀に無人岩も存在する。宮の浜では， 幅 $5 \mathrm{~m}$ のデイサイト岩脈の中央に幅 $3 \mathrm{~m}$ の無人 岩が貫入する複合岩脈が見られる (Kuroda et al., 1988)。これらの岩脈の走向は北西ないし東 西で，傾斜は緩いものが多く平均 $45^{\circ}$ 東落ちであ る(丸山ほか, 1989)。これは父島東岸の平行岩脈 群が枕状溶岩層をほぼ垂直に切り, 南北ないし北 西走向をもつのと対照的である。

\section{III. 無人岩平行岩脈群}

父島に見られる火山岩層の最下部である無人岩 枕状溶岩層は，下部ほど岩脈の割合が多くなる。 そのさらに最下部があらわれる石浦では，岩脈が 露頭面積の半ば以上を占めることがある。

図 2 と 3 に石浦北海岸における岩脈の産状を示 す。DIN 1 から DIN 8 の間では約 $60 \%$ が岩脈に よって占められる。岩脈の幅は $10 \mathrm{~cm}$ から $3 \mathrm{~m}$ 以上にわたるが，0.5〜 $2 \mathrm{~m}$ のものが最も多い。 走向は $\mathrm{NS}$ から $\mathrm{N} 50^{\circ} \mathrm{W}$ ，傾斜は $60 \sim 70^{\circ} \mathrm{E}$ である。 枕状溶岩層は西に $20 \sim 30^{\circ}$ で傾くので，岩脈は層 理面にほぼ垂直に貫入していることになる。しば

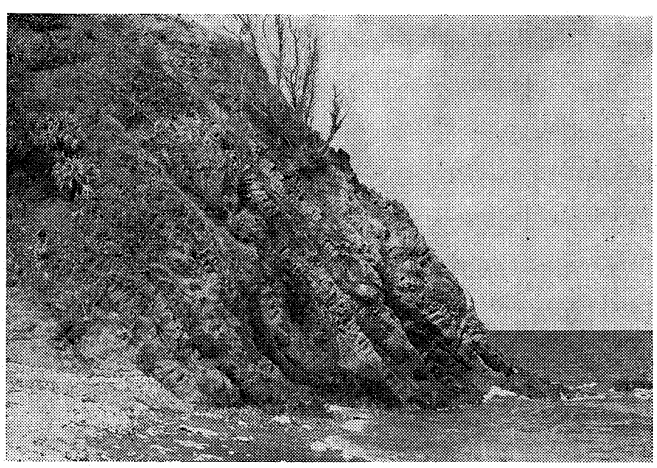

図 3 石浦北海岸の岩脈（DIN1-DIN8）

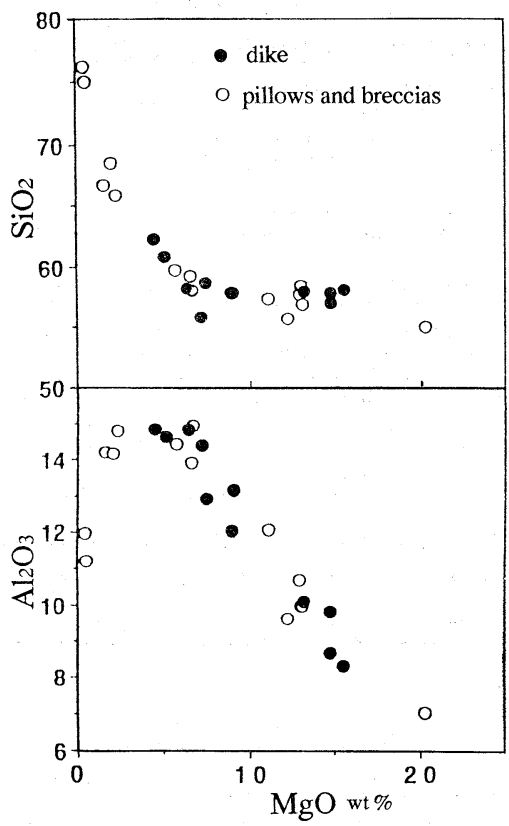

図 4 石浦・初寝浦岩脈と父島東部枕状溶岩・角礫 岩の $\mathrm{MgO}$ に対する $\mathrm{SiO}_{2}$ と $\mathrm{Al}_{2} \mathrm{O}_{3}$ の変 化図

しば複合岩脈をつくり，また分岐・尖滅すること もある。同様な平行岩脈群は石浦南海岸にもあら われる。そこでは高さ $50 \mathrm{~m}$ 以上の海蝕崖が海中 に没する最東端で, 岩脈の密度が最大に達するよ らに見える。

図 4 亿石浦・初寝浦地域の岩脈と父島東部地域 の枕状溶岩・角䃋岩をつくる岩石の, $\mathrm{MgO}$ に対 する $\mathrm{SiO}_{2}$ と $\mathrm{Al}_{2} \mathrm{O}_{3}$ の変化図を示す。 $\mathrm{SiO}_{2} 63$ \%以上のデイサイト・流紋岩は，本地域以外のも 
のも含んでいる。石浦・初寝浦地域の岩脈は主に 無人岩と古銅輝石安山岩である。無人岩は定義に より斜長石をもたないので, 斜長石の晶出したも のを古銅輝石安山岩とする。無人岩は一般に古銅 輝石安山岩に比べて $\mathrm{MgO}$ が高く, 石浦の岩脈に はしばしば単斜頑火輝石が含まれる。岩脈の周縁 部が無人岩, 徐冷した中心部が古銅輝石安山岩と なることもある。古銅輝石安山岩の中には分化が 進み, $\mathrm{MgO} 6 \%$ 以下のものもある。しかし，本 地域の岩脈からは $\mathrm{SiO}_{2} 63 \%$ 以上のデイサイトは 見出されなかった。

石浦・初寝浦地域の岩脈と枕状溶岩・角礫岩は 全く同一のトレンド上に載る。これは平行岩脈群 が無人岩・古銅輝石安山岩枕状溶岩・角砂岩と同 一マグマ源であることを示している。

\section{IV. 無人岩は拡大軸で生じたか}

無人岩枕状溶岩層の最下部があらわれる父島東 海岸の石浦付近に見られる平行岩脈群は，比較的 未分化の無人岩と古銅輝石安山岩からなり，他地 域の岩脈が主にデイサイトであることと異なる。 また，下部にいくほど岩脈が多くなり，最東端で は岩脈の割合が $50 \%$ 以上に達する。これは，いく つかのオフィオライトから知られ, 海洋底桩大の 直接的証拠とされる，層状岩脈群を窥わせるもの である。

白木ほか（1985）は先に，無人岩は水と $\mathrm{SiO}_{2}$ の多いことを除けば，拡大する海領でつくられる 岩石の特徴と一致することを示した。それは，1） $\mathrm{MgO} \cdot \mathrm{Cr} \cdot \mathrm{Ni}$ に富む未分化岩の割合が高い，2) 低圧 $(<30 \mathrm{~km}) \cdot$ 高温 $\left(>1,300^{\circ} \mathrm{C}\right)$ 下でマント ルかんらん岩から分離した，3）急激に上昇し深 海底に噴出した可能性が高い，などであった。

さらに，無人岩のあらわれる父島・聟島列島は 島弧としては世界最大の正の重力異常值をもち, それから算定される地殼の厚さは $8 \mathrm{~km}$ である。 $8 \mathrm{~km}$ という地殼の厚さは海洋地殼の厚さ $5 \sim 10$ $\mathrm{km}$ とあまり異ならない。すなわち，父島・聟島 列島は薄い海洋地款からなる樑海底が，なんらか の原因で海面上にあらわれたと見ることも可能で ある。
以上のことから, 無人岩は深部から高温の物質 が上昇する一種の拡大中心に，サブダクションに よって水が供給されたとき生じ, 海洋底拡大を行 ない，薄い海洋地殼をつくった，と考えられる。 もしこれが事実であるならば，無人岩の生成には サブダクションと拡大という，いわば全く相反す る過程が近接して同時に起こったことになり，そ の地質条件が極めて興味深い。

\section{文献}

Crawford, A.J. ed. (1989): Boninites. Unwin Hyman, London, $465 \mathrm{p}$.

菊池 安 (1988)：小笠原島及火山群島地質摘要. 東洋 学芸雑誌, 5-77, 64-69.

Kuroda, N. and Shiraki, K. (1975) : Boninite and related rocks of Chichi-jima, Bonin Islands, Japan. Rep. Fac. Sci. Shizuoka Univ., 10, 145-155.

Kuroda, N., Shiraki, K. and Urano, H. (1988): Ferropigeonite quartz dacites from Chichi-jima, Bonin Islands: Latest differentiates from boninite -forming magma. Contrib. Mineral. Petrol., 100, 129-138.

丸山茂德 - 松本謙一 - 倉元豊秋 - 山口達弘 - 白木敬一 斎藤聡一・黒田 直・浦野隼臣 (1989)：小笠原諸島 兄島の地質. 白木敬一編：日本の高マグネシア安山岩. 山口大学理学部, 35-40.

Pearce, J.A., Lippard, S.J. and Roberts, S. (1984) : Characteristics and tectonic significance of suprasubduction zone ophiolites. Geol. Soc. Lond. Spec. Publ., 16, 77-94.

Petersen, J. (1891) : Beitäge zur Petrographie von Sulphur Island, Peel Island, Hachijo und Mijakeshima. Jahrb. Hamburg. Wiss. Anst., 8, 1-59.

Robinson, P.T., Melson, W.G., O'Hearn, T. and Schmincke, H.-U. (1983) : Volcanic glass compositions of the Troodos ophiolite, Cyprus. Geology, 11, 400-404.

白木敬一 (1988)：日本に㧍ける学術ボーリング候補地 （2）小笠原諸島一世界初のモホールに向けて——. 月刊地球, 10, 247-251.

白木敬一 (1989)：高マグネシア安山岩について. 白木 敬一編：日本の高マグネシア安山岩. 山口大学理学部, $5-25$.

白木敬一・藤岡換太郎 (1992)：島弧はどのようにして 成長してきたか一伊豆小笠原マリアナ弧の発達史 —. 月刊地球, 14, 473-477.

白木敬一・黒田 直 (1977)：無人岩再訪. 地学雑誌, $86,174-190$.

白木敬一・黒田 直 - 浦野隼臣・Nesbitt， R. W. (1985)：小笠原諸島父島・聟島一ママントルにいち ばん近い島一、. 月刊地球, 11，632-637。 
白木敬一・黒田 直・浦野隼臣 (1987)： キプロス島卜 ルドス・オフィオライトのいわゆる無人岩 : 小笠原無 人岩との比較. $M A G M A, 81,7-11$.
Umino, S. (1985): Volcanic geology of Chichijima, the Bonin Islands (Ogasawara Islands). J. Geol. Soc. Japan, 91, 505-523. 